\title{
Comparative Political Economy and International Migration
}

\author{
Alexandre Afonso, Leiden University \\ Camilla Devitt, Trinity College Dublin
}

\begin{abstract}
This article provides an overview of the literature connecting comparative political economy and international migration in advanced industrialised countries with a focus on the relationship between labour migration, labour markets and welfare institutions. Immigration flows and policies are considered both as independent (how migration shapes capitalist institutions) and dependent variables (how migration flows and policies are shaped by capitalist institutions). First, we discuss the impact of international migration on labour market institutions, welfare states and skill production regimes. Second, we discuss how labour market institutions and welfare arrangements shape migrant inflows and migration policies, notably via the structuration of interests of employers, organised labour and governments. We emphasise the ideas of liberalisation, segmentation, substitution and complementarity to grasp the relationship between immigration and labour market institutions.
\end{abstract}

Keywords: immigration, comparative political economy, welfare states, industrial relations, institutional analysis.

JEL codes: P51; J01; F22

Word count: 11472

\section{Introduction}

International migration has come to the forefront of both political and economic debates in advanced industrial democracies. This issue regularly polls as the most important topics of concern for citizens, and features at the centre of electoral campaigns in both Europe and North America. This high political salience is paralleled by the growing significance of immigration in modern labour markets (Oesch 2013: 83). Between 2003 and 2013, international migrants contributed to $70 \%$ of the increase in the workforce in Europe and $47 \%$ in the United States, where the foreign-born population no less than tripled between 1970 and 2007 (OECD 2014: 1; Garand et al. 2015: 1). As a phenomenon with wide-ranging implications for the governance of labour markets, the welfare state and the macro-economy as a whole, immigration has become difficult to ignore for scholars interested in the interactions between politics and markets. 
Yet, immigration is still often ignored in mainstream comparative political economy (see, however, Freeman \& Kessler 2008; Freeman 2004; McGovern 2007). There is now a growing body of research in political science, sociology and economics addressing how immigration may reshape socio-economic institutions (the welfare state, industrial relations and skill production) in different countries, but it seldom engages explicitly with frameworks mapping capitalist models (Freeman 2004: 953). How does immigration influence welfare states, industrial relations and skill production regimes in different countries? In turn, do these institutions create different types and levels of demand for migrant workers? What is the relationship between levels of coordination in the economy and immigration policies? At present, we lack a comprehensive picture of the links between international migration and capitalist diversity which could inform future research agendas. Against this background, this article has two main objectives. First, it seeks to outline how comparative political economists can factor in the role of international immigration to explain institutional change and continuity in capitalist models. Second, it shows how migration scholars can incorporate insights from mainstream comparative political economy to explain migration flows and migration policies.

To these ends, this paper presents recent research connecting international migration and the core institutions of capitalist models, and proposes avenues for future research. After outlining conceptual linkages between socio-economic institutions and immigration, the paper discusses first whether and how immigration (re-)shapes capitalist institutions within three spheres (labour market institutions; the welfare state; skill production), and then assesses how capitalist institutions and actors (labour, business and governments) shape immigration flows and immigration policies. Hence, we consider immigration alternatively as an explanatory variable and as a variable to be explained. These are not competing but complementary perspectives. On the one hand, a focus on immigration sheds light on the context in which capitalist institutions originate and change over time. On the other, taking socio-economic institutions into account can help explain the nature and size of immigration flows, as well as the characteristics of immigration policies in different political economies.

Throughout our review, we highlight a number of mechanisms whereby immigration interacts with labour market institutions, namely liberalisation, segmentation (immigration as an instrument which allows the reconciliation of protection and flexibility), complementarity (between immigration and different labour market institutions) and substitution (how immigration fulfils functions otherwise carried out by other institutions). These mechanisms are mentioned throughout the text, emphasising the complex relationships of causality between capitalism and immigration. 
We restrict our scope in a number of ways to provide a comprehensive but focused literature review. ${ }^{1}$ First, we concentrate on labour migration flows and policies and leave aside other forms of migration, such as asylum, forced migration or family reunification. This choice is justified by the central importance of economic factors in driving labour migration flows (McGovern 2007: 219) and the closer connection between labour migration and the core institutions of advanced economies emphasised in the literature. For these reasons, we also focus on labour market and welfare institutions and do not address corporate governance or financial institutions.

Second, the discussion engages principally with the (institutional) comparative political economy agenda, defined as a "diverse set of approaches and analytical frameworks [which] [...] compare how institutional diversity impacts economic performance outcomes across advanced industrial countries" (Jackson \& Deeg 2007: 149-150; see Hall and Soskice 2001; Amable 2003; Hollingsworth \& Boyer 1997). ${ }^{1}$ In spite of their differences, the frameworks we draw on classify capitalist models based on the extent to which demand and supply are "embedded" in social and political rules which constrain market forces (Hollingsworth \& Boyer 1997; Hall \& Gingerich 2004). Within the universe of OECD countries, an important emphasis is placed on the distinction between the coordinated market economies (CMEs) of Continental Europe, Scandinavia, Japan and Korea and the AngloSaxon liberal market economies (LMEs) (United Kingdom, United States, Australia, New Zealand) (Thelen 2014: 1; see Figure 1). Within this context, we focus on macro-institutions and leave aside work focusing on the micro-level in economic sociology (e.g. Portes 1995). Work in anthropology or geography also falls outside the scope of this review.

\section{How Immigration Interacts with Capitalist Institutions}

Following McGovern (2007: 218), we believe that immigration raises theoretically important questions for comparative political economy as a whole, and that the way immigration interacts with capitalist institutions can be captured with concepts used in other areas of the discipline. We outline four of these concepts, which can be found in the different areas we review here: liberalisation, segmentation, complementarity, and substitution. These should be considered as recurring threads in the different types of interaction we cover.

\subsection{Liberalisation vs. Segmentation}

One important idea throughout the literature is that immigration creates economic and political divisions that can undermine the social and political embedding of markets. A question to be addressed is whether this translates into the outright liberalisation of political 
economies, or their differentiation through segmentation. While liberalisation is a process whereby institutions (multi-employer collective bargaining, state-administered social programmes) are replaced by sheer market forces, segmentation is the idea that markets become divided into separate submarkets or segments, distinguished by different characteristics and behavioural rules, for instance between workers in stable and unstable employment (Deakin 2013: iii). Hence, coordination can coexist alongside competition.

The connection between immigration, liberalisation and segmentation is underlain by the idea that migrants' economic behaviour is less shaped by local norms and institutions than that of native workers, making them a more commodified form of labour (Piore 1979: 52-53). Early on, Sombart (1928: 883) argued for instance that migration strengthens the capitalist spirit by breaking with traditional habits and social norms that constrain entrepreneurship, allowing for economic innovation. Because of their weaker social and political resources, migrants may be prone to accept more flexible terms of employment, lower wages, worse employment conditions, and be more mobile geographically.

In the late $19^{\text {th }}$ century, Engels (1987) [1887] already described Irish migrants in Britain as a core component of the "industrial reserve army" used by capitalists to drive down workers' wages and ensure a large supply of labour that could be disposed of during recessions (Engels 1987: 133; Hollifield 1994: 22; Castles \& Kosack 1972)2. ${ }^{1}$ Within Marxian analysis, immigrants also fulfilled a political function by dividing the working class and undermining class consciousness. For Marx (1870), the hostility between Irish and English proletarians was the "secret of the impotence of the English working class," enabling capitalists to maintain their power by exploiting divisions within the labour movement. Following this line of argument, immigration is an instrument of liberalisation, undermining the capacity of the working class to constrain and regulate market forces.

However, immigration may also make it possible to reconcile the flexibility requirements of a market economy (for migrants) with the protection requirements of society (for natives), thereby addressing a central concern of Polanyi’s (1957) Great Transformation. The main mechanism through which this takes place is segmentation. The "dual labour market" theory proposed by Piore (1979) drew heavily on this idea of segmentation, and posited that labour markets in advanced industrial countries were divided between a primary sector characterised by secure, protected jobs with higher wages, populated almost exclusively by native workers, and a secondary sector characterised by precarious employment, low wages and bad working conditions, populated predominantly by migrants. Within the dual labour market model, immigration did not necessarily exert downward pressure on the wages of natives, as the two groups are not in direct competition with each other (for an overview of segmentation theory and immigration, see McGovern 2007: 225- 
226). Linked to this, a burgeoning research agenda dealing with "dualisation" has recently emerged, tying in with important political debates about the increase in income inequality (Emmenegger et al. 2012; Emmenegger \& Careja 2012; King \& Rueda 2008).

The idea of segmentation is important for current debates about institutional change, because it makes it possible to envisage the co-existence of solidaristic non-market arrangements (collective bargaining; welfare state arrangements), which are often understood as sources of rigidity, alongside a segment of flexible, "cheap" (migrant) labour (King and Rueda 2008). In the typology of liberalisation trajectories proposed by Thelen (2014: 12-15), this corresponds to the difference between outright deregulation, signalling a convergence to the sheer supply-and-demand mechanisms and commodified labour outlined above, and dualisation, meaning a process of segmentation with different levels of embeddedness across labour market segments. Hence, immigration may be a way to shield, rather than undermine, existing coordinated arrangements.

\subsection{Substitution vs. Complementarity}

The ideas of substitution and complementarity refer to the function that immigration fulfils vis-à-vis other socio-economic institutions in capitalist models. These ideas have notably been applied to the interactions of public and private regulation (e.g. corporate social responsibility): private regulation may either substitute rules that the state does not enforce, or bolster public rules through some form of institutional isomorphism (Locke et al. 2013).

On the one hand, immigration can substitute institutions that do not exist or fail to deliver a particular outcome. A good example here is education and skills: when vocational training institutions do not train enough workers to satisfy firms' needs (say in carpenters, bricklayers or plumbers), this creates a skills mismatch and a potential demand for foreign workers. In this context, immigration can substitute training institutions by enabling firms to source skilled workers from overseas. In turn, a large supply of foreign-trained workers can hinder the development of training institutions - as in the case of early training in the United States or replace them. For domestic firms, a steady supply of skills produced abroad "for free" can remove incentives to provide these skills domestically through training. Another example is the welfare state: in Southern European countries, for instance, where care and social services are underdeveloped, and where the welfare system is heavily biased towards cash transfers, migrant workers employed informally often provide care for children or the elderly in a context where the formal welfare state has failed to cope with social needs. Following this logic, immigration compensates the shortcomings of existing (public) institutions, but it can also compete with and hinder them. 
On the other hand, immigration can complement existing institutions by mirroring their logic of functioning. For instance, LMEs specialising in radical innovation, enabled by a flexible labour market and the availability of venture capital may yield better returns with an immigration policy favouring high-skilled workers with general skills. In contrast, a CME specialising in incremental innovation may favour migrant workers with specialised skills who will be more easily employed. Liberal market economies emphasising general skills may also be more open to immigration in general, as foreign workers are easier to integrate in such systems . Hence, within a logic of complementarity, immigration does not substitute or compete with existing institutional arrangements, but may rather reinforce them.

Following these two logics, one can expect immigration to yield different impacts on institutional arrangements, either by undermining institutional mechanisms through substitution, or strengthening them through complementarity. We will now address this relationship, referring to these mechanisms as recurring threads.

\section{The Impact of Migration on Models of Capitalism}

Since 1990, the number of international migrants in advanced industrial countries has increased by 65\%, reaching about 231 million in 2013 (OECD 2013). Migration flows have particularly intensified in the 10 -year period that preceded the global financial crisis, with a slowdown afterwards. There is substantial variation across countries in levels of immigration. In Figure 1, we plot this variation (measured as the number of incoming migrants per year divided by the population) against the index of coordination devised by Witt and Jackson (2016), which captures the degree of market embeddedness we mentioned above. On average, more liberal political economies tend to receive more migrants than coordinated economies, even if the correlation between coordination and immigration levels is not very strong $(r=-$ $0.34)$.

In the following sections, we seek to unpack this relationship. We begin by addressing the impact of migration flows on capitalist institutions, focusing on labour market institutions, the welfare state, and skill production. 


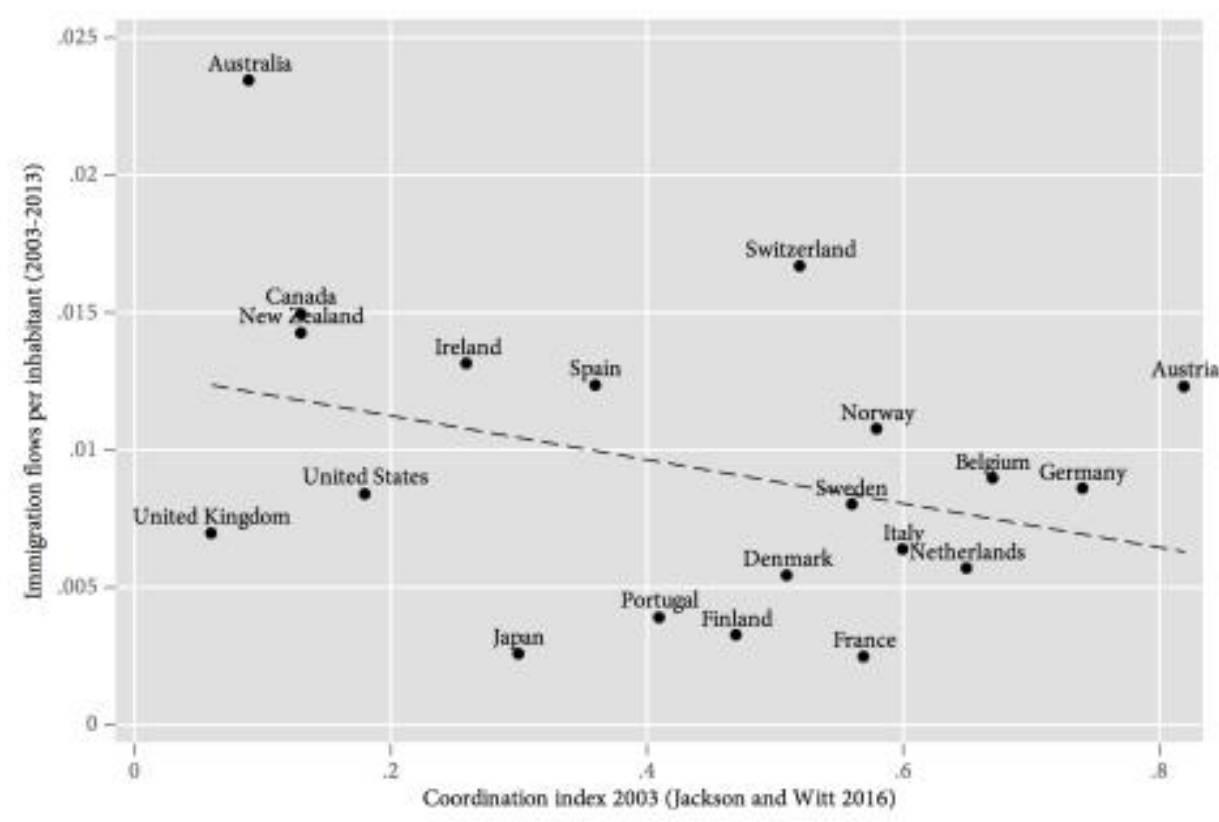

Source: Witt and Jackson 2016; OECD migration \& population databases

\subsection{Labour Market Institutions}

The debate about the impact of immigration on labour market institutions has mostly revolved around whether labour migration is a "Trojan horse" of liberalisation or a buffer against liberalisation by way of segmentation. As an example of the first hypothesis, Streeck (1995: 23) argued for instance in the mid-1990s that the breakdown of Communism had "unleashed an inflow of immigrants (to Germany) of a dimension that in the long term seems incompatible with high labour standards, an extended welfare state, and a normalized pattern of high-wage and high-skill employment.". While a combination of tight immigration controls and on-the-job training had previously allowed the German economy to absorb waves of guest-workers from Turkey and Southern Europe without challenging its organised system of industrial relations, the large supply of cheap labour triggered by the fall of the iron curtain would undermine the ability of trade unions to exert control over the labour market, and pave the way for far-reaching liberalisation.

An important idea behind this was that the stability of organised systems of industrial relations was made possible by the ability of trade unions and public authorities to control the labour supply via immigration control. Hence, immigration control was implicitly considered complementary to domestic coordination (Bucken-Knapp 2009). If this ability decreases, the bargaining power of unions declines, and coordination unravels because of the sheer size and more commodified nature of migrant labour flows. Recent research on the free movement of workers and services in the European Union similarly argued that increased labour mobility, 
combined with the possibility for employers to formally employ workers in low-wage countries and "post" them in high-wage countries, were undermining coordinated market arrangements by allowing employers to circumvent the power of unions (Afonso 2012; Dolvik \& Visser 2009; Lillie \& Greer 2007; Menz 2010; Wagner 2014; Bengtsson 2016; Donaghey and Teague 2006).

From the alternative perspective, the use of migrant labour can make it possible for coordinated arrangements to resist the pressures of globalisation by developing flexibility at the margins through segmentation (Palier \& Thelen 2010). Arguably, importing cheaper migrant labour can be a substitute for exporting jobs to countries with lower wages. For instance, immigration made it possible for Switzerland to absorb international economic shocks in the 1970s without bearing their social costs and to preserve its core socio-economic arrangements. The departure of about 200,000 migrants on temporary stay permits made it possible to partly externalise the costs of economic change onto foreign workers who were not entitled to unemployment protection at the time, limiting the effects of the recession on native workers (Fluckiger 1998: 371). Along similar lines, Raess and Burgoon (2013) find that companies with greater shares of migrant workers are more likely to introduce measures of "external" flexibility such as fixed-term, temporary agency and employer-mandated parttime work contracts and are less likely to increase "internal" flexibility such as overtime work. In the 1960s, German unions accepted the establishment of guest-worker programs because they knew that this would facilitate the reduction of working time for their clientele (Herbert 2000: 204). Here again, immigration may act as a buffer enabling flexibility without challenging the security that characterises employment within the primary labour market.

\subsection{Welfare States}

The most rapidly expanding area of research seeking to assess the impact of immigration on the political economy of rich democracies is certainly the one linking immigration to the support for and viability of the welfare state (Alesina \& Glaeser 2004; Burgoon et al. 2012; Burgoon 2014). We differentiate between approaches addressing functional logics and political logics. In both, the idea of segmentation plays a prominent role.

As regards functional logics, a major research question has been the extent to which immigration strengthens or undermines the fiscal sustainability of the welfare state. Freeman (1986) outlined early on the contradictions between the logic of closure of the welfare state and the logic of openness inherent to the movement of labour across borders. Welfare states, he argued, were not sustainable if a shrinking base of contributors has to fund benefits for a potentially unlimited number of recipients coming from abroad. In this perspective, restrictive immigration control was again considered complementary to generous welfare protection. 
Regarding the actual impact of immigration on welfare, available evidence tends to indicate different impacts across schemes (Boeri 2010). In many countries, immigrants are on average less skilled, more often unemployed and have more children than natives, and are therefore believed to resort disproportionately to welfare programmes such as unemployment, childand housing benefits (Boeri 2010; OECD 2008). However, old-age pensions represent by far the biggest spending item of most advanced welfare states and migrants, who tend to be younger on average, are more often net contributors to this scheme.

General estimates of the net fiscal burden of immigration tend to point to an overall small net burden on average for European countries (less than 1\% of GDP; for an overview, see Burgoon 2014: 367-368), with differences across countries and types of migration (notably between EU- and non-EU). An interesting question would consist in determining whether different welfare regimes, as proposed by Esping-Andersen (1990), are more or less subject to these pressures. Insofar as immigrants tend to be net recipients of universal schemes and net contributors to contributory schemes, one could expect the contributionheavy Bismarckian system to be more "immigration proof" than universal systems because they allow for higher levels of segmentation in rights. For fear of "welfare tourism", a number of countries operating universal welfare schemes have for instance enforced stricter entitlement criteria in the aftermath of the latest EU enlargements, leading to a more segmented distribution of rights (Kvist 2004; Carmel et al. 2011). European integration has played an important role in how immigration may affect welfare. Expectations in this respect are ambiguous. Caporaso and Tarrow (2009) argue for instance that the principle of nondiscrimination promoted by the European Court of Justice (ECJ) is part of a "Polanyan" shift towards the increasing regulation of markets, while authors such as Scharpf (2010) argue that the principle of labour and service mobility that has been enforced by the ECJ in a number of rulings makes the survival of generous welfare states difficult.

Research which investigates the political logics mostly focuses on how immigration may affect support for welfare and redistribution. An idea prominently championed by Alesina and Glaeser (2004) is that citizens support welfare programmes if they benefit individuals with whom they can identify. In other words, solidarity is segmented socially and ethnically. As a vector of increasing ethnic heterogeneity, immigration tends to undermine this feeling of identification and lower support for extensive welfare programmes if they are perceived to disproportionately benefit ethnic "others". Garand et al. (2015: 8-9) recently found that immigration attitudes have a powerful effect on support for welfare, and the way people think about immigration is a strong predictor of how they think about welfare generosity and spending. 
According to Alesina and Glaeser, the prevalence of ethnic divisions is one of the major factors behind the limited development of redistributive policies in the United States, as compared to European countries. Lipset and Marks (2000: 125-166) also argued that ethnic divisions within the American working class crowded out class consciousness and thwarted cohesive class-based organisations which could have pushed for a bigger redistributive effort (Burgoon et al. 2010; Mink 1986: 45; Tichenor 2002). Lieberman (1998) makes a similar argument, with interesting variations across schemes. In contrast, European welfare arrangements built in the interwar and immediate post-war period emerged at a time when fairly restrictive migration policy regimes were in place, and where ethnic homogeneity prevailed (Bade 2008). Here again, immigration control could be considered complementary to generous welfare provision. Drawing on this, Alesina and Glaeser predicted that high levels of immigration into European welfare states could lead to the "Americanisation" of European welfare. If citizens perceive redistribution to benefit "underserving" strangers, support for the welfare state will decline, and liberalisation will ensue. Immigration should therefore pave the way for declining levels of redistribution, and a convergence towards the leaner US model of welfare. This thesis, however, has been contested. Brady and Finnigan (2014) do not find a significant relationship between indicators of immigration and opposition to welfare policies, and argue that there may be greater potential for the opposite hypothesis: welfare may be used as a compensation mechanism for the higher level of competition brought about by immigration.

Indeed, high immigration, and therefore increasing labour market competition, may create higher economic insecurity amongst native workers and bolster demands for social protection from the state. For instance, Burgoon et al. (2012) find no link between migration experienced at the national level and support for redistribution, but migration experienced in the workplace is associated with higher support for redistribution. More recently, Burgoon (2014) found that the relationship between immigrant stocks and support for redistribution is mediated by levels of integration: natives are more likely to oppose redistribution if immigrants are less integrated economically. Crepaz (2008: 161) analyses the mediating effect of different forms of trust and welfare regimes on attitudes towards welfare, and finds that immigration does not systematically undermine support for the welfare state, however with different results across social groups and welfare regimes. Universal regimes, for instance, tend to reduce the level of welfare chauvinism of natives, while targeted, residual regimes are more prone to the emergence of ethnic conflict about welfare. Finally, Schmidt and Spies (2013) find that the behaviour of political parties, namely whether they use the "race card" or not, also mediates how migration impacts on welfare attitudes. 
Another interesting line of research connecting labour immigration to welfare relates to gender, and whether women and migrants can function as substitutes on the labour market. For example, Naumann (2005) argued that Swedish trade union concerns about the impact of labour immigration in the 1960s and their view of female participation as a 'lesser evil' resulted in the setting up of an extensive public childcare infrastructure to support female employment instead of importing (male) foreign workers. Similarly, Devitt (2016) argues that the opening up of the Irish labour market to workers from the new EU member states in 2004 reduced the urgency to provide further public support to working mothers by strengthening the childcare infrastructure. Relating this to the mechanisms highlighted above, open immigration policies may act as (possibly imperfect) substitutes to policies facilitating female employment.

\subsection{Skill Production and Training}

Though less explored in the literature, immigration can also influence the development of skill production and training regimes (for an overview of the literature, see Busemeyer \& Trampusch 2011). As mentioned above, immigration can be considered as a functional substitute to education systems insofar as training and immigration are the "only two ways for a nation to secure an adequate supply of skilled workers" (Toner \& Woolley 2008: 48). In some ways, this challenges the implicit methodological nationalism of the comparative political economy literature. It is for instance difficult to speak of a self-sufficient system of skill production in the US given that so many skills are produced abroad. Sourcing skilled foreign workers may be a more profitable short-term strategy for firms as long as they can free-ride on the skills produced by other countries. It is of course unlikely that immigration can cover all the skill needs of a particular country, but it can play a prominent role in particular historical periods and in certain labour sectors.

In her comparison of skill formation regimes in Germany, the US, Japan and Britain, Thelen (2004: 180) shows for example that the skills which early industries in the US relied on were not created domestically, as in Germany or Britain, but sourced through immigration. This possibly removed, at least initially, incentives for firms and governments to cooperate to generate these skills. Thelen also shows that ethnic heterogeneity and labour mobility also prevented the emergence of cohesive labour unions, which could control skilled labour markets and restrict access to outsiders on the basis of skills. In her analysis, these early forms of protection are the forerunners of modern forms of interest organisation. Later on, changes in the composition of immigration flows and the wider availability of low-skilled migrant labour created the structural conditions for mechanised production techniques, and weakened the importance of crafts and skilled labour which, in Europe, was able to secure political 
protection and regulate labour markets. Hence, open borders hindered the emergence of coordination arrangements, highlighting the mechanisms of substitution between immigration and institutions.

More recently, various contributors in Ruhs and Anderson's (2010) edited volume on labour migration in the UK make a similar argument about the relationship between skill production and immigration, showing how companies in some sectors have increasingly relied on skills produced abroad and invested less in the production of skills domestically. For example, Chan, Clarke and Dainty (2010) argue that the broader range of skills of many migrants in the British construction industry disadvantages those trained in Britain, where vocational training has notoriously been weakly developed. The deregulatory trend in this sector has discouraged firms from cooperating to produce skills domestically. In the light of mass popular hostility to immigration, it has however also been argued that tighter migration policies could result in efforts to strengthen education and training institutions, thereby producing more skills domestically and reducing the reliance on foreign workers. Opting for training rather than immigration may be considered safer by employers, considering that the availability of foreign labour depends on economic developments beyond their control, such as the labour market situation in other countries. Given the increasingly anti-immigration stance adopted by a number of governing parties in Europe, notably in the UK, the policy context may become unfavourable (Devitt 2011).

For the United States, Wright and Dwyer (2003: 309) put a great deal of emphasis on the role of Hispanic migration to explain changes in the skills and occupational structure of the US labour market in the 1990s. They argue that the skill polarisation - and the elated increase in income inequality - that took place during this period was largely due to an increase in the low-skilled migrant labour supply - essentially from Mexico - at the bottom end of the labour market. Between 1994 and 2000, immigrants filled 58\% of newly created jobs below the median and $64 \%$ in the bottom quintile, following a very similar dynamic of segmentation as the one analysed by Piore (1979). As immigration flows are unevenly distributed across skill levels, they can also play a significant role in patterns of inequality across countries. If immigration is concentrated on low-wage sectors, inequality will increase. Wage progression will be slower in the lower segments of the labour market due to a more abundant labour supply. However, evidence seems to show that this primarily affects migrant workers themselves because natives and migrants are imperfect substitutes due to the dynamics of segmentation highlighted above (Card 2009). Moving beyond the national level, immigration can also function as a mechanism of international redistribution since it works against the pattern of capital accumulation that drives inequality (Piketty 2014: 538). 


\section{Models of Capitalism as Determinants of Immigration Flows}

We now move to an examination of the other side of the relationship, namely how the institutional setup of capitalist models shape international migration. If capitalist systems have been affected by inflows of foreign labour and skills, capitalist arrangements also naturally exert an influence on immigration flows and immigration policies (Freeman 2004: 953-958). The underlying idea of approaches investigating this relationship is that the institutional features of political economies shape employer demand for migrant workers and migrants' incentives to choose particular destinations. This can happen via complementarity and substitution mechanisms.

A handful of scholars have recently argued that, rather than being determined by labour market parameters only (growth, unemployment, wage differentials), the size and types of labour migration inflows are shaped by the particular institutional setup of labour markets (Devitt 2011; Ruhs \& Anderson 2010). For instance, a low level of collective bargaining coverage can create more opportunities for low-wage employment, where migrant workers tend to be concentrated. One implicit idea in the literature is that immigration is used to compensate for a lack of complementarity between skill formation, welfare institutions and the labour market. For instance, Ruhs and Anderson's (2010) edited volume shows that immigration is used to compensate for the weak complementarity between inflexible benefits systems and housing markets which constrain the mobility of native workers, and the weakly regulated labour market requiring high levels of flexibility, creating a mismatch that is filled with migrant labour. Hence, the surge in labour migration to Britain from the late 1990s onwards can be partly traced back to deregulation and the demise of training as firms started competing on price only (Wright 2012: 126). Construction, in which a very large part of the workforce is both foreign and self-employed, is one typical example where firms have resorted to immigration to source craft labour instead of cooperating to produce skills domestically.

Using a version of the complementarity argument, Devitt (2011) argues that varying levels and types of labour immigration across Western Europe reflect different socioeconomic regimes. She notably aims to explain why the Nordic European states received fewer migrant workers than other Western European states in the decade preceding the economic downturn of 2008 in spite of similar levels of immigration control. The UK, Ireland and Sweden opened up their labour markets to workers from the new EU member states in 2004, yet Sweden received far smaller inflows than the other two states. Furthermore, belying the common assumption that labour shortages are simply a function of economic growth, Italy and Germany experienced both low employment levels and high levels of labour immigration in the 1990s. Nordic regimes drawing on high wage floors and higher skills create lower 
demand for low-skilled migrant workers than Liberal, Southern Statist regimes and some Conservative-Continental regimes with large low-wage/low-skill sectors, where it is easier to employ foreign workers on low wages. Hence, welfare, education and training institutions diversely shape the availability and skills of domestic workers, impacting on the demand for labour migrants. In many ways, these findings contradict the widely held idea that generous welfare arrangements foster larger immigration flows. Large welfare states generally mean high taxes and wage floors, which may reduce the attractiveness of low-skilled migrants.

Borjas's (1999) welfare-magnet thesis, which on the basis of US data argued that more generous benefits led to more migration, has to date provided elusive results in a crossnational setting (Morrissons 2008; Pedersen et al. 2006; Thielemann 2006). Analysing 16 countries between 1985 and 2002, Schulzek (2012) finds for instance that generous welfare systems act as pull factors for asylum seekers but not for labour migrants. Controlling for GDP growth, unemployment, a country's liberal reputation, network ties and geography, she finds that the generous welfare provisions of social democratic welfare states attract asylum seekers but deter labour migrants. Corporatist regimes attract both types of migrants, while Liberal welfare states deter asylum seekers and do not attract labour migrants. However, lacking reliable comparative indicators, Schulzek is not able to control for the restrictiveness of immigration policy.

One interesting line of research explores how welfare states may attract labour migrants not only as potential recipients of benefits, but as providers of services. In this setting, immigration acts as a substitute to welfare service provision. Van Hooren (2012: 136) shows for instance how the deficiencies of state-funded eldercare in Italy have been compensated by the employment of large numbers of female migrant workers providing care at home, often in informal employment. Hence, the failure of welfare state arrangements to keep pace with societal developments - the process that Hacker (2005) calls policy drift - has created a demand for low-wage migrant labour. In contrast, the extensive care services provided by the Swedish welfare state have not created significant demand for migrant labour. In the UK, cuts in spending on social care have placed greater cost pressures on private care providers, which have come to rely on an ever greater number of migrant workers ready to accept lower wages and asocial working hours (Shutes 2013; van Hooren 2012: 137). Hence, the weak development of welfare arrangements, or their retrenchment, can lead to greater demand for migrant labour providing low-wage care services. Private services by migrants work act as a functional substitute to the public provision of welfare. 


\section{Models of Capitalism as Determinants of Migration Policies}

A major factor shaping migration flows is immigration control, and it is worth assessing the relationship between capitalist models and immigration policies. ${ }^{3}$ The literature covered here seeks to explain policies rather than flows. The underlying idea is that institutional arrangements shape the preferences of governments, employers and trade unions regarding migrant labour, and their influence on immigration policy outputs. We first focus on analyses considering the system of political economy as a whole (macro-level), and then highlight (meso/micro) approaches focusing more on the role of specific actors: organised labour; employers; and parties.

\subsection{Macro-Institutions and Immigration Policies}

Interest group politics has been considered to play a prominent role in influencing labour migration policy. In an influential framework, Freeman (1995) sought to explain why immigration policies in liberal democracies were far more liberal than public opinion warrants. Drawing on Olson's (1982) theory on the size of groups, Freeman argued that immigration has concentrated benefits and diffuse costs: the groups who have a special interest in high immigration levels, such as employers and migrant advocacy groups, are better placed to organize and influence policy-makers than the general public, that bears the diffuse costs of immigration but is more difficult to mobilise (Freeman 1995). This specific distribution of costs and benefits creates a form of client politics fostering immigration policy openness. Freeman's model has, however, been criticized for disregarding the influence of institutional and cultural norms that happen to be central for comparative political economists (Statham \& Geddes 2006; Zolberg 1999). Indeed, the model does not leave much room for variation across countries.

Recent work has sought to combine the idea of comparative capitalism with immigration policy in a way that takes institutional diversity into account. Ruhs (2013: 77) found for example that liberal market economies are more likely to impose immigration restrictions based on the individual characteristics of migrants (e.g. education and language), while coordinated market economies are more likely to impose restrictions in the types of jobs offered to migrants (e.g salary conditions; compliance with collectively agreed wages; specific sectors). This may suggest that LMEs seek to attract migrants that will complement their innovation potential, while CMEs seek to ensure that immigration does not threaten established wages and working conditions. Moreover, LMEs where firms draw on general rather than specific skills, and where employers are more prone to "poach" workers trained elsewhere, can be expected to adopt more liberal immigration policies. On the other hand, 
employers in CMEs may want to use labour migrants to fill gaps in radical product innovation as their education and training systems are more geared towards incremental change. More recently, Wright (2012: 127-128) has also connected the increasing liberalisation of labour migration policies in LMEs such as the UK or Australia with a voluntarist system of training, which failed to provide adequate skills. Here again, immigration and training policies appear as substitutes.

Differentiating countries by their degree of openness to trade, Peters (2015) has recently found that immigration and trade policy appear to maintain a relationship of substitution as well: countries that adopt an open trade policy choose restrictive immigration policies and vice versa. If they cannot import cheaper goods because of trade restrictions, domestic firms will lobby to import migrant labour instead, and so will the firms in labourintensive sectors protected by the restrictions. In contrast, when trade is opened the size of labour-intensive industries declines, and so does the demand for low-skilled foreign labour. This is the main reason why, according to Peters, the $19^{\text {th }}$ century was a time of open immigration but closed trade, while the $20^{\text {th }}$ witnessed open trade but (more) closed borders. Peters develops an indicator of immigration restrictiveness that spans over four centuries.

After reviewing approaches focusing on macro-institutions, we now turn to the role of socio-economic actors in shaping immigration policies: organised labour, employers, and the state.

\subsection{Organised Labour}

Trade unions have long been perceived as preferring a restrictive migration policy for economic and political reasons. First, immigration control limits the labour supply and prevents wage depression (Castles \& Kosack 1972: 134; Mink 1986; Penninx \& Roosblad 2000: 4; Watts 2002: 1). For instance, in the first half of the $20^{\text {th }}$ century, US organised labour spearheaded a successful campaign for immigration restriction (Tichenor 2002: 203). Second, immigration can lead to a fragmentation of the workers' movement due to cultural and language differences, and undermine its political power. Immigrants may be less easy to organise because of their more transient legal status (Krings 2010; Turner et al. 2008; for a critique, see Burgoon et al. 2010: 966).

A hypothesis deriving from this is that stronger labour movements would lead to more restrictive immigration policies. Trade union power may for instance explain the limited development of guest-worker programmes in Scandinavia, where organised labour has traditionally been strong, as opposed to countries such as France, Germany, Austria or Switzerland (Knocke 2000). In the 1960s, the Swedish labour movement chose to support female participation in the labour market instead of increasing the recruitment of foreign 
workers (Bucken-Knapp 2009; Naumann 2005: 54). Moreover, since unions insisted on stable stay permits and the full integration of guest workers into the social security system, it was more difficult for employers to segment the workforce and take advantage of migrants' lower wage claims (Knocke 2000: 164). The use of guest-worker programs in Bismarckian welfare states, in contrast, aimed to expand the labour supply without challenging the male breadwinner model on which these systems relied. It drew more heavily on the segmentation of rights, and complemented the institutional features of the welfare state. The import of mostly male - migrant workers was considered preferable to increasing female participation and challenging traditional gender roles (Herbert 2001: 204).

From the early 2000s, however, scholars started challenging the view that trade unions are necessarily opposed to open labour migration policies. Some unions in the US and Europe started to support legal channels for labour immigration, and place more emphasis on the organisation of migrants (Watts 2002, Milkman 2006, Tapia and Turner 2013). This can be accounted for by a pragmatic acceptance that full immigration control could not be effectively achieved (Joppke 1998). The effective enforcement of employment standards has progressively been seen as a more effective way to protect the labour market than migration control, which may create irregular flows that are difficult to monitor. In this context, crossclass coalitions between unions and employers in support of more open immigration policies could emerge, however with stances mediated by other factors, such as the size of the informal labour market (Watts 2002: 73).

Krings (2009) has shown that some labour movements take a more restrictive stance than others. When eight countries from central and eastern Europe joined the EU in 2004, most member states imposed a transitional period due to concerns about the labour market impact of labour migration (Zahn 2011). Krings highlights the different stances of German and Austrian unions on the one hand, who favoured restrictions on labour movement, and British and Irish unions, who supported their government's open labour market policies. The weak British labour movement was the most in favour of open borders, thereby supporting the theory that unions with low levels of political influence favour organizing migrant workers over restricting inflows (Haus 2002). Nonetheless, unions are generally more focused on the situation and treatment of migrants present in the country than the management of channels of entry (Caviedes 2010; Krings 2009).

\subsection{Employers}

Caviedes (2010) argues that employers' associations are the most influential actors in labour migration policy-making. He argues, in contrast to hypotheses derived from $\mathrm{VoC}$, that sector- 
specific labour requirements are relatively uniform across different political economies, and he expects firms' preferences to differ across economic sectors rather than countries. Caviedes's model of employers' preferences highlights their interest in improving the numerical, temporal and wage flexibility of their workforce. Seasonal and short-term labour permits make it possible for employers in sectors exposed to international cycles to cope with ups and downs. In low-productivity sectors such as agriculture or domestic services, in contrast, employers have an interest in maintaining a constant downward pressure on wages and consequently favour policies that provide migrants with a different status to domestic workers, thereby segmenting the labour market. However, Caviedes may underestimate diversity within sectors. National labour market regulations and enforcement mechanisms result in differing employment standards within the same sector across states (Hjarno 2003). Besides, employer preferences are shaped by and aggregated within employer confederations, which can mediate the demands of particular sectors. Employer associations must consider trade union preferences and their organizational strength, as well as the political viability of their demands in the face of public opinion (Afonso 2012).

Afonso (2012) distinguishes between the tradable and non-tradable sectors in explaining the immigration policy preferences of employers. Companies which trade internationally are expected to favour unregulated labour mobility as a way to reduce production costs. Employers in non-tradable sectors, however, may perceive labour mobility as a threat if foreign service providers can bring in their cheaper employees while complying with lower wage standards. Afonso highlights 'cross-class coalitions' between trade unions and employers, but to support more closed - rather than more open - immigration policies because employer interests are aligned with those of unions. Drawing on Korpi (2006), he argues that the choice of strategy is influenced by power relationships between pro- and antiregulation firms within national employer associations; trade union power resources; and the threat of unilateral public intervention driven by public opinion.

\subsection{Parties and Governments}

We finish the review of actors with parties and state actors. In political economy accounts, political parties are generally seen as less central than interest groups in shaping migration policy due to the greater proximity of employers and unions to labour market concerns. Besides, there is often little difference between centre-right and centre-left parties in their labour migration positions (Alonso \& Da Fonseca 2012). Generally, it is assumed that both left- and right-wing parties face similar incentives in light of the generally restrictive position of voters, at least when it comes to low-skilled migration. 
However, the extent to which this restrictionist sentiment is channelled from voters to policymakers can be mediated by political institutions. Breunig and Luedtke (2008) show for instance that majoritarian electoral institutions tend to foster more restrictive immigration policy agendas because of the more direct link between the preferences of the median voter and policies, while corporatist and multiparty systems tend to temper electoral pressures for restriction. This could for instance explain the longstanding restrictionist consensus in the United Kingdom until the early 2000s (Hansen 2000; Devitt 2012).

Besides, political and bureaucratic institutions can be important factors in explaining the openness of labour migration policies not only with regard to electoral pressures, but also interest group influence. Bartram (2004) argues for instance that the closure of Japan to migration has been due in part to the strong Japanese developmental state and its independent bureaucracy able to resist employer lobbying. This, combined with a deep-rooted attachment to cultural homogeneity, may explain why Japan has resisted tendencies to expand immigration in spite of very low fertility rates and a quickly ageing population (Bartram 2000). In contrast, the Israeli clientelistic bureaucracy could be more easily penetrated by business interests lobbying for cheap labour. Boswell (2012) and Afonso (2007) focus on (economic) expertise in the field of immigration policymaking, showing how expert advice within and outside bureaucracies can independently frame policy problems, but also be used by politicians to justify their own policy agendas.

Moving away from the assumption that voter preferences are uniform, other authors explain migration policies by the social and economic setup of party constituencies. Looking at high-skilled immigration policies, Cerna (2009) argues that the preferences of political parties' core constituencies explain differences in levels of openness to highly skilled immigration across countries. A core constituency of native high-skilled workers is expected to result in a restrictive highly skilled immigration policy. She assumes that high-skilled voters will oppose open high-skilled immigration policies because of labour market competition, while low-skilled labour will support it because of complementarity effects (Cerna 2009: 149). However, contradicting this claim with empirical evidence, Hainmueller and Hiscox (2010) find that both low- and high-skilled workers favour high- over low-skilled migration, and therefore find no support for protectionist stances among high-skilled workers. Hence, it may appear that high-skilled voters are aware that migrants play a complementary rather than substitution function in the labour market.

While there is often a basic consensus regarding labour immigration systems across the centre-right and centre-left, this does not mean that parties do not have an important agenda-setting function in this area. This is particularly the case in times of economic downturn when electoral competition, particularly from radical right parties, motivates 
governments to restrict labour immigration regardless of employers' needs (Schain 2006). One important research agenda in the future would be to ascertain when economic interests drive labour migration policies, and when more political concerns restrict the ability of economic actors to shape it. Hence, political economy accounts would be greatly enhanced by loosening the theoretical straitjacket of interest group dominance and presenting a more nuanced picture. For instance, it seems reasonable to expect that interest group politics and liberal policies play a more prominent role when immigration has lower salience, while political, potentially restrictionist, policies prevail when immigration gains salience, and politicians are spurred to listen to voters rather than interest groups. This could draw on the framework proposed by Culpepper (2010) to analyse the relationship between salience and regulation.

\section{Conclusion}

In this article, we have presented a number of approaches linking the comparative analysis of national political economies with immigration flows and immigration policies. In spite of the diversity of areas covered, we have argued that they can be connected by a number of common concepts, namely liberalisation, segmentation, substitution and complementarity. To conclude, we emphasise the need to better integrate migration and comparative capitalisms research and outline a number of possible research agendas tying together the themes discussed above.

First, research on comparative capitalism would benefit greatly from an expansion of its focus to include labour immigration because it often constitutes a "hidden" substitute to many policies considered important in the literature. Immigration policy can be analysed as an economic policy that shapes the labour supply just like active labour market policies or vocational education and training. As such, the regulation of immigration should be integrated into models of capitalist diversity. This would, for example, provide better insights into the mechanisms of skill production, especially in countries where immigration is a significant source of labour. Moreover, it would also help introduce a transnational dimension and overcome the risk of "methodological nationalism" that often underpins comparative political economy (Wimmer and Schiller 2003): immigration highlights how policies in one country can shape institutions in another country. Related to this, comparative insights can also shed light on the differential impact of immigration on labour markets. A large body of research on the economic impact of immigration is based on evidence from the United States - the "welfare magnet" hypothesis is a case in point - and often ignores the important institutional differences between labour markets in Europe and North America. 
Second, we have highlighted the effects of high levels of labour immigration on collective bargaining, welfare states and skills systems. An important underlying question that still needs to be explored is how immigration has reshaped the partisan and class coalitions supporting modern political economies. Migration potentially augments the mismatch between the constituency performing activities in the market (constituted by an increasing share of disenfranchised migrants) and the one exerting political rights (mostly restricted to natives). This challenges many of the core assumptions of political economy analysis, which emphasise the interactions between democracy (a system of decision-making based on votes) and capitalism (a system of exchange based on resources). Indeed, one important insight from political economy research is how groups that were dominated in the market were able to use politics to redistribute resources and regulate markets (Boix 2003; Esping-Andersen 1992; Korpi 1983). The fact that a significant proportion of low-income workers nowadays are immigrants raises important questions about the capacity of low-income groups to seek state intervention in markets. This influence is arguably mediated by citizenship laws: where access to citizenship is easier, immigration may empower the left. The "ethnic vote" (AfricanAmerican, Hispanics and Asians) has for instance given a presidential majority to Barack Obama in 2008 and 2012, while John McCain and Mitt Romney commanded clear majorities among whites, whose share of the electorate has declined from 89\% in 1976 to $72 \%$ in $2012 .{ }^{4}$ In other countries where access to citizenship is more restrictive, left parties are deprived from an important constituency, and spurred to appeal to "socio-cultural professionals" with different economic preferences. Meanwhile, the native white working class has been presented as the core base of support of anti-immigration parties in Europe (Kriesi et al. 2008), and of Donald Trump's presidential bid in the 2016 US general election .

Third, an important agenda for future immigration research is the assessment of the impact of labour market and welfare institutions on immigration. While a number of authors have addressed how welfare and labour market arrangements may attract migrants in a small number of cases, we lack systematic cross-national evidence on how the institutional characteristics of welfare states and industrial relation systems act as magnets or deterrents for migration flows. One major problem in carrying out this agenda so far has been the lack of reliable data to control for the restrictiveness of immigration policy across countries and across time. The recent development of immigration policy restrictiveness indicators should now make this possible (see Bjerre et al. 2014; Beine et al. 2014). Since a growing number of governments are seeking to restrict access to welfare in order to reduce immigration, it is important to have systematic comparative evidence to engage with the popular "welfare magnet" hypothesis. It is necessary to go beyond social spending as an indicator of welfare generosity, and differentiate between welfare schemes. Spending per se says little about how 
accessible welfare might be for migrants. Generous unemployment benefits or family benefits are perhaps more likely to function as immigration "magnets" than pension benefits.

Finally, drawing on the idea that immigration often responds to mismatches between the native labour supply and available jobs, it would be important to assess the impact of labour market reforms not directly related to immigration (e.g. welfare retrenchment or changes in employment protection) on migrant flows. This would shed light on the mechanisms of complementarity and substitution between immigration policy and other areas of economic policy, such as trade, welfare and labour market regulation. Immigration studies, for their part, are often not explicit enough about the socio-economic context in which immigration takes place (as opposed to integration regimes). Taking into account institutional diversity should therefore be a fruitful way to understand how immigration shapes and is shaped by capitalism.

\section{References}

Afonso, A. (2007) "Policy Change and the Politics of Expertise. Economic Ideas and Immigration Control Reforms in Switzerland”, Swiss Political Science Review 13(1): 1-38. (2012) "Employer Strategies, Cross-Class Coalitions and the Free Movement of Labour in the Enlarged European Union”, Socio-Economic Review 10(4): 705-730.

Alesina, A., and E.L. Glaeser (2004) Fighting Poverty in the US and Europe, Oxford: Oxford University Press.

Alonso, S., and S. da Fonseca (2012) "Immigration, Left and Right", Party Politics 18(6): 865-884.

Amable, B. (2003) The Diversity of Modern Capitalism. Oxford: Oxford University Press.

Bade, K. (2008) Migration in European History. London: Wiley.

Bartram, D. (2000) "Japan and labor migration: Theoretical and methodological implications of negative cases", International Migration Review 34(1) : 5-32.

Bartram, D. (2004) "Labor Migration Policy and the Governance of the Construction Industry in Israel and Japan”, Politics \& Society 32(2): 131-170.

Beine, M, B. Burgoon, M. Crock, J. Gest, M. Hiscox, P. McGovern, H. Rapoport and E. Thielemann (2014) "Measuring Immigration Policies: Preliminary Evidence from IMPALA", CESifo Working Paper Series No. 5109.

Bengtsson, E. (2016) "Social dumping cases in the Swedish Labour Court in the wake of Laval, 2004-2010”. Economic and Industrial Democracy 37(1), 23-42. 
Bjerre, L., M. Helbling, F. Römer, and M. Zobel (2014) "Conceptualizing and Measuring Immigration Policies: A Comparative Perspective", International Migration Review 49(3): $555-600$.

Boeri, T. (2010) "Immigration to the Land of Redistribution", Economica 77(308): 651-687.

Boix, C. (2003) Democracy and Redistribution. Cambridge: Cambridge University Press.

Borjas, G.J. (1999) “Immigration and Welfare Magnets", Journal of Labor Economics 17(4): 607-637.

Boswell, C. (2012) The Political Uses of Expert Knowledge. Cambridge: Cambridge University Press.

Brady, D., \& Finnigan, R. (2013). “Does Immigration Undermine Public Support for Social Policy?" American Sociological Review 79(1): 17-42.

Breunig, C., and A. Luedtke (2008) "What Motivates the Gatekeepers? Explaining Governing Party Preferences on Immigration", Governance 21(1): 123-146.

Bucken-Knapp, G. (2009) Defending the Swedish Model: Social Democrats, Trade Unions, and Labor Migration Policy Reform. Lanham: Rowman \& Littlefield.

Burgoon, B. (2014) "Immigration, Integration and Support for Redistribution in Europe", World Politics 66(3): 365-405.

Burgoon, B., J. Fine, W. Jacoby, and D. Tichenor et al. (2010) "Immigration and the Transformation of American Unionism", International Migration Review 44(4): 933-973.

Burgoon, B., F. Koster, and M. Van Egmond et al. (2012) "Support for Redistribution and the Paradox of Immigration", Journal of European Social Policy 22(3): 288-304.

Busemeyer, M.R., and C. Trampusch (2011) "Review Article: Comparative Political Science and the Study of Education”, British Journal of Political Science 41(2): 413-443.

Caporaso, J.A., and S. Tarrow (2009) "Polanyi in Brussels: Supranational Institutions and the Transnational Embedding of Markets", International Organization 63(4): 593-620.

Card, D. (2009) "Immigration and Inequality" American Economic Review, 99(2): 1-21.

Carmel, E., A. Cerami, and T. Papadopoulos (eds) (2011) Migration and Welfare in the New Europe. Bristol : Policy Press.

Castles, S., and G. Kosack (1972) “The Function of Labour Immigration in Western European Capitalism", New Left Review 73): 3-21.

Caviedes, A.A. (2010) Prying Open Fortress Europe: The Turn to Sectoral Labor Migration. Lanham: Rowman \& Littlefield.

Cerna, L. (2009) "The Varieties of High-Skilled Immigration Policies: Coalitions and Policy Outputs in Advanced Industrial Countries", Journal of European Public Policy 16(1): 144161.

Chan, P, Clarke, L. and Dainty, A. (2010) "The dynamics of migrant employment in construction: can supply of skilled labour ever match demand?" In Ruhs, M., and B. 
Anderson (2010) Who Needs Migrant Workers? Oxford: Oxford University Press: 225255.

Clift, B. (2014) Comparative Political Economy. London: Palgrave.

Cornelius, W.A. (2004) Controlling Immigration : A Global Perspective. Stanford, Calif.: Stanford University Press.

Crepaz, M.M.L. (2008) Trust Beyond Borders: Immigration, the Welfare State, and Identity in Modern Societies. University of Michigan Press.

Culpepper, P. (2010) Quiet Politics: Business Power and Corporate Control. Cambridge: Cambridge University Press.

Deakin, S. (2013) Addressing Labour Market Segmentation: The Role of Labour Law. Geneva: ILO.

Deeg, R., and G. Jackson (2007) "Towards a More Dynamic Theory of Capitalist Variety", Socio-Economic Review 5(1): 149-179.

Devitt, C. (2011) "Varieties of Capitalism, Variation in Labour Immigration", Journal of Ethnic and Migration Studies 37(4): 579-596.

Devitt, C. (2012) The Governance of Labour Migration in the Uk. Turin: FIERI.

Devitt, C. (2016) “Mothers Or Migrants? Labour Supply Policies in Ireland 1997-2007”. Social Politics 23(2): 214-238.

Dolvik, J.E., and J. Visser (2009) "Free Movement, Equal Treatment and Workers' Rights: Can the European Union Solve Its Trilemma of Fundamental Principles?", Industrial Relations Journal 40(6): 491-509.

Donaghey, J., \& Teague, P. (2006) "The free movement of workers and social Europe: maintaining the European ideal". Industrial Relations Journal, 37(6), 652-666.

Eichhorst, W. (2000) Europäische Sozialpolitik Zwischen Nationaler Autonomie Und Marktfreiheit. Frankfurt: Campus Verlag.

Emmenegger, P., S. Häusermann, B. Palier, and M. Seeleib-Kaiser et al. (2012) The Age of Dualization. Oxford: Oxford University Press.

Emmenegger, P., and R. Careja (2012) "From Dilemma to Dualization: Social and Migration Policies in the "Reluctant Countries of Immigration", in Emmenegger, P., S. Häusermann, B. Palier, and M. Seeleib-Kaiser (eds) The Age of Dualization. Oxford: Oxford University Press.

Engels, F. (1987) The Condition of the Working Class in England. London: Penguin UK. Esping-andersen, G. (1992) Politics Against Markets. Princeton: Princeton University Press. Esping-Andersen, G. (1990) The Three Worlds of Welfare Capitalism. Cambridge: Polity Press. 
Estevez-Abe, M., Iversen, T., \& Soskice, D. (2001). "Social protection and the formation of skills: a reinterpretation of the welfare state" in Hall, P. and Soskice, D. (eds) Varieties of Capitalism, Oxford: Oxford University Press, 145-175.

Fluckiger, Y. (1998) “The Labour Market in Switzerland: The End of a Special Case?", International Journal of Manpower 19(6): 369-395.

Freeman, G.P., and A.K. Kessler (2008) "Political Economy and Migration Policy", Journal of Ethnic and Migration Studies 34(4): 655-678.

Freeman, G.P. (1995) "Modes of Immigration Politics in Liberal Democratic States", International Migration Review 29(4): 881-908.

_ (2004) "Immigrant Incorporation in Western Democracies", International Migration Review 38(3): 945-969. ${ }^{5}$

Freeman, G.P. (1986) "Migration and the Political Economy of the Welfare State", The Annals of the American Academy of Political and Social Science 48: 551-63.

Garand, J., Xu P., and Davis, B. (2015) "Immigration Attitudes and Support for the Welfare State in the American Mass Public." American Journal of Political Science, online ahead of print.

Guiraudon, V. (2014). "Economic crisis and institutional resilience: The political economy of migrant incorporation." West European Politics, 37(6): 1297-1313.

Hacker, J. (2005) "Policy Drift: The Hidden Politics of Us Welfare State Retrenchment" in Streeck, W. and Thelen, K. (eds) Beyond continuity: Institutional change in advanced political economies. Oxford: Oxford University Press: 40-82.

Hagen-Zanker, J., and R. Mallett (2013) How to Do a Rigorous, Evidence-Focused Literature Review in International Development. London: ODI.

Hainmueller, J., and M.J. Hiscox (2010) “Attitudes Toward Highly Skilled and Low-Skilled Immigration: Evidence from a Survey Experiment", American Political Science Review 104(1): 61-84.

Hall, P.A., and D.W. Soskice (eds.) (2001) Varieties of Capitalism. Oxford: Oxford University Press.

Hall, P. A., \& Gingerich, D. W. (2004). Varieties of Capitalism and Institutional Complementarities in the Macroecnomy, MPIfG Discussion Paper 4(5).

Hansen, R. (2000) Citizenship and Immigration in Post-War Britain: The Institutional Origins of a Multicultural Nation. Oxford University Press, USA.

Haus, L.A. (2002) Unions, Immigration, and Internationalization: New Challenges and Changing Coalitions in the United States and France. New York: Palgrave Macmillan.

Herbert, U. (2001) Geschichte der Ausländerpolitik in Deutschland. Munich: Beck.

Hjarno, J. (2003) Illegal Immigrants and Development in Employment in the Labour Markets. Aldershot: Ashgate. 
Hollifield, J.F. (1992) Immigrants, Markets and States. The Political Economy of Postwar Europe. Cambridge MA: Harvard University Press.

Hollingsworth, J.R., and R. Boyer (1997) Contemporary Capitalism: The Embeddedness of Institutions. Cambridge: Cambridge University Press.

Hunger, U. (2000) Der , Rheinische Kapitalismus ' in Der Defensive. Baden-Baden: Nomos.

Iversen, T. (2006) "Capitalism and Democracy" in Weingast, B., and W. Wittman (eds.) The Oxford Handbook of Political Economy. Oxford: Oxford University Press: 601-624.

Joppke, C. (1998) "Why Liberal States Accept Unwanted Migration", World Politics 50): 266-293.

King, D., and D. Rueda (2008) "Cheap Labor: The New Politics of "Bread and Roses" in Industrial Democracies", Perspectives on Politics 6(2): 279-297.

Knocke, W. (2000) "Sweden: Insiders Outside the Trade Union Mainstream" in Penninx, R., and J. Roosblad (eds.) Trade Unions, Immigration, and Immigrants in Europe, 1960-1993. New York: Berghahn books: 157-183.

Korpi, W. (2006) "Power Resources and Employer-Centered Approaches in Explanations of Welfare States and Varieties of Capitalism: Protagonists, Consenters, and Antagonists", World Politics 58(2): 167.

Korpi, W. (1983) The Democratic Class Struggle. London: Routledge.

Kriesi, H., E. Grande, R. Lachat, M. Dolezal, S. Bornschier, and T. Frey et al. (2008) West European Politics in the Age of Globalization. Cambridge: Cambridge University Press.

Krings, T. (2009) "A Race to the Bottom? Trade Unions, EU Enlargement and the Free Movement of Labour", European Journal of Industrial Relations 15(1): 49-69.

_. (2010) “Trade Unions and Migrant Labour in the 'Global Age': New Alliances or Old Antagonisms?" in Menz, G., and A. Caviedes (eds.) Labour Migration in Europe. Basingstoke: Palgrave Macmillan:

Kvist, J. (2004) "Does EU Enlargement Start a Race to the Bottom? Strategic Interaction Among EU Member States in Social Policy", Journal of European Social Policy 14(3): 301.

Lehndorff, S. (2012) A Triumph of Failed Ideas: European Models of Capitalism in the Crisis. Brussels: ETUI.

Lieberman, R. (1998) Shifting the Color Line. Chicago: Chicago University Press.

Lillie, N., and I. Greer (2007) "Industrial Relations, Migration, and Neoliberal Politics: The Case of the European Construction Sector", Politics \& Society 35(4): 551-581.

Lipset, S.M., and G. Marks (2000) It Didn't Happen Here: Why Socialism Failed in the United States. New York: Norton 
Marx, K. (1870) "Letter to Siegried Meyer and Karl Vogt in New York", https://www.marxists.org/archive/marx/works/1870/letters/70_04_09.htm

McGovern, P. (2007) "Immigration, Labour Markets and Employment Relations: Problems and Prospects", British Journal of Industrial Relations 45(2): 217-235.

Menz, G. (2010) “Are You Being Served? Europeanizing and Re-Regulating the Single Market in Services", Journal of European Public Policy 17(7): 971-987.

Menz, G. (2003) "Re-Regulating the Single Market: National Varieties of Capitalism and Their Responses to Europeanization”, Journal of European Public Policy 10(4): 532-555.

(2005) Varieties of Capitalism and Europeanization: National Response Strategies to the Single European Market. Oxford: Oxford University Press.

(2009) The Political Economy of Managed Migration: The Role of Unions, Employers, and Non-Governmental Organizations in a Europeanized Policy Domain. Oxford: Oxford University Press.

Milkman, R. (2006) LA Story: Immigrant Workers and the Future of the Us Labor Movement. New York : Russell Sage Foundation.

Mink, G. (1986) Old Labor and New Immigrants in American Political Development: Union, Party, and State, 1875-1920. Ithaca: Cornell University Press.

Morrissons, A. (2008) "Immigrants, Unemployment and Europe's Varying Welfare Regimes." in Parsons, C., and T. Smeeding (eds.) Immigration and the Transformation of Europe. Cambridge: Cambridge University Press: 172-199.

Naumann, I.K. (2005) "Child Care and Feminism in West Germany and Sweden in the 1960s and 1970s", Journal of European Social Policy 15(1): 47-63.

OECD (2008) A Profile of Immigrant Populations in the 21st Century: Data From OECD Countries. Paris: OECD.

- (2013) World Migration in Figures. Paris: OECD

(2014) Is Migration Good or Bad for the Economy? Paris: OECD Migration Policy Debates.

Oesch, D. (2013) Occupational Change in Europe: How Technology and Education Transform the Job Structure. Oxford University Press.

Olson, M. (1982) The Rise and Decline of Nations. New Haven: Yale University Press.

Palier, B., and K. Thelen (2010) "Institutionalizing Dualism: Complementarities and Change in France and Germany", Politics \& Society 38(1): 119-148.

Pedersen, P.J., M. Pytlikova, and N. Smith et al. (2006) "Migration Into OECD Countries 1990-2000", in Parson, C. and Smeeding, T. (eds) Immigration and the Transformation of Europe. Cambridge: Cambridge University Press.

Penninx, R., and J. Roosblad. (2000) "Introduction" in Penninx, R., and J. Roosblad (eds.) Trade Unions, Immigration, and Immigrants in Europe, 1960-1993: A Comparative Study 
of the Attitudes and Actions of Trade Unions in Seven West European Countries. New York: Berghahn books: 1-21.

Peters, M.E. (2015) "Open Trade, Closed Borders Immigration in the Era of Globalization", World Politics 67(1): 114-154.

Piketty, T. (2014). Capital in the Twenty-First Century. Cambridge, MA: Harvard University Press.

Piore, M. (1979) Birds of Passage: Migrant Labour and Industrial Societies. Cambridge: Cambridge University Press.

Polanyi, K. (1957) The Great Transformation. Boston: Beacon Press.

Portes, A. (1995) "Economic Sociology and the Sociology of Immigration: A Conceptual Overview" in Portes, A. (ed.) The Economic Sociology of Immigration: Essays on Networks, Ethnicity and Entrepreneurship. New York: Russell Sage Foundation:

Raess, D., and B. Burgoon (2013) "Flexible Work and Immigration in Europe", British Journal of Industrial Relations 53(1): 94-111.

Ruhs, M. (2013) The Price of Rights: Regulating International Labor Migration. Princeton: Princeton University Press.

Ruhs, M., and B. Anderson (2010) Who Needs Migrant Workers? Labour Shortages, Immigration, and Public Policy. Oxford: Oxford University Press.

Schain, M.A. (2006) "The Extreme-Right and Immigration Policy-Making: Measuring Direct and Indirect Effects", West European Politics 29(2): 270-289.

Scharpf, F.W. (2010) "The Asymmetry of European Integration, Or Why the Eu Cannot be a ‘social Market Economy”, Socio-Economic Review 8(1): 211-250.

Schmidt, A.W., and D.C. Spies (2013) "Do Parties "Playing the Race Card" Undermine Natives' Support for Redistribution? Evidence From Europe", Comparative Political Studies 0010414013488542.

Schmidt, V.A. (2002) The Futures of European Capitalism. Oxford University Press.

Schulzek, N. (2012) The Impact of Welfare Systems on Immigratopm. London: LSE Migration Policy Unit.

Shutes, I. (2013) "Long-Term Care and Migrant Labour in the Uk" in Jurado, E., and G. Brochmann (eds.) Europe's Immigration Challenge. London : IB Tauris: 125-142.

Sombart, W. (1928) Der Moderne Kapitalismus. Munich: Duncker \& Humblot.

Statham, P., and A. Geddes (2006) 'Elites and the 'organised Public': Who Drives British Immigration Politics and in Which Direction?", West European Politics 29(2): 248-269.

Streeck, W. (1995) German Capitalism: Does it Exist? Can it Survive? Cologne: MPIfG Discussion Paper 95(5). 
Tapia, M., and L. Turner (2013) "Union Campaigns as Countermovements: Mobilizing Immigrant Workers in France and the United Kingdom", British Journal of Industrial Relations 51(3): 601-622.

Thelen, K. (2014) Varieties of Liberalization and the New Politics of Social Solidarity. Cambridge University Press.

Thelen, K.A. (2004) How Institutions Evolve: The Political Economy of Skills in Germany, Britain, the United States, and Japan. Cambridge: Cambridge University Press.

Thielemann, E.R. (2006) "The Effectiveness of Asylum Policy in Controlling Unwanted Migration", Immigration and the Transformation of Europe

Tichenor, D.J. (2002) Dividing Lines: The Politics of Immigration Control in America. Princeton, N.J.; Oxford: Princeton University Press.

Toner, P., and R. Woolley (2008) "Temporary Migration and Skills Formation in the Trades: A Provisional Assessment",

Turner, T., D. D'art, and M. O’Sullivan et al. (2008) “Union Availability, Union Membership and Immigrant Workers: An Empirical Investigation of the Irish Case", Employee Relations 30(5): 479-493.

Van Hooren, F.J. (2012) "Varieties of Migrant Care Work: Comparing Patterns of Migrant Labour in Social Care", Journal of European Social Policy 22(2): 133-147.

Wagner, I. (2014) "Rule Enactment in a Pan-European Labour Market: Transnational Posted Work in the German Construction Sector", British Journal of Industrial Relations (ahead of print).

Watts, J.R. (2002) Immigration Policy and the Challenge of Globalization. Ithaca: Cornell University Press.

Weingast, B., and D. Wittman. (2008) The Oxford Handbook of Political Economy. Oxford: Oxford University Press.

Wimmer, A., and Schiller, N. G.. (2003). "Methodological Nationalism, the Social Sciences, and the Study of Migration: An Essay in Historical Epistemology". International Migration Review, 37(3): 576-610.

Witt, Michael A, and G. Jackson (2016) "Varieties of Capitalism and Institutional Comparative Advantage: A Test and Reinterpretation”. Journal of International Business Studies, advance online publication.

Wright, C.F. (2012) "Immigration Policy and Market Institutions in Liberal Market Economies: Immigration Policy and Market Institutions", Industrial Relations Journal 43(2): 110-136.

Wright, E.O., and R.E. Dwyer (2003) "The Patterns of Job Expansions in the USA: A Comparison of the 1960s and 1990s", Socio-Economic Review 1(3): 289-325. 
Zahn, R.L. (2011) "Trade Unions and New Member State Workers in Germany and the United Kingdom", International Journal of Comparative Labour Law and Industrial Relations 27(2): 139-164.

Zolberg, A.R. (1999) Matters of State: Theorizing Immigration Policy. na.

\section{Notes}

${ }^{1}$ Systematic literature reviews can be carried out using different methods, namely a systematic literature search based on pre-defined search terms in academic search engines such as Web of Science or Google Scholar, and the snowballing method starting with a few core texts and and connecting them to cited works to expand the corpus (Hagen-Zanker and Mallett 2013). We mainly used the snowballing method. We found this method more suitable because the connection between immigration and economic institutions is often implicit and therefore difficult to detect in search engines based on keywords and words present in titles. We used snowballing in both directions, starting with widely cited works in mainstream political economy, which draw implications for immigration (forward), and works explicitly connecting immigration with political economy (backward). We aim for depth rather than exhaustiveness, highlighting mechanisms of connection rather than seeking to provide an exhaustive list of works making these connections.

${ }^{2}$ In line with this idea, recent research shows for instance that the employment of immigrants in the United States is more closely tied to the business cycle than that of natives (Orrenius and Zadovny 2009).

3 The relationship between immigration and the restrictiveness of immigration policy can be ambiguous: liberal immigration policies do not always result in higher levels of inward migration if labour demand, particularly for low-skilled workers, is low. In contrast, restrictive labour immigration policies, in a context of employer demand for foreign workers, can result in high levels of irregular labour immigration (Cornelius 2004).

${ }_{5}^{4}$ Source : Roper center, http://ropercenter.cornell.edu/polls/us-elections/. 5 